\title{
Application of budgeting tools to cut structural imbalances in regional development
}

\author{
Natalia Romanova ${ }^{1, *}$, Nadezhda Anisimova ${ }^{2}$ and Ivan Provotorov ${ }^{2}$ \\ ${ }^{1}$ Department of economic development of Voronezh region, Lenin square 1, Voronezh, 394000, \\ Russia \\ ${ }^{2}$ Voronezh State Technical University, 14, Moskovsky prospect, Voronezh, 394026, Russia
}

\begin{abstract}
Today priorities in the growth of the regions and the need to reduce imbalances in its development requires to work out the theoretical and methodological approach to the feasibility of financial support of the regions and to the study of applications of budgeting tools in order to eliminate the asymmetry and to improve investment activity of municipalities. The authors studied the causes and the sequences of uneven development of territories; the experience to balance the economic growth of Voronezh region was analyzed. There were given recommendations on calculating the level of co-financing of the expenditure commitments of the municipality from the regional budget and illustrated the efficiency of applying budgeting tools to a specific facility in one of the regions.
\end{abstract}

\section{Introduction}

Sustainable and balanced socio-economic development of territories is a strategic priority of state policy. Achieving the economic growth, that is vital to bring the country to a new level, is impossible without reducing the imbalance that exists in the social and production sphere due to objective and subjective reasons in various regions. Objectively, from the macroeconomic point of view, all territories cannot have the same level and potential of development, but significant differences usually reflect in the social sphere and can even breach its stability. In this regard, the problem of eliminating economic imbalances and reducing asymmetries in the development of the subjects of the Russian Federation, municipalities, settlements is one of the pressing issues from both the general theoretical point of view and the practical implementation of specific regulatory mechanisms aimed at changing the current situation. Various opinions are expressed in scholarly literature where financial, institutional and other mechanisms for eliminating the engineering and manufacturing as well as territorial-sectoral imbalances in the development of regions of the country are proposed. Practically, actual tools are actively used in the regions in order to reduce the asymmetry in the economic and social development of territories within the structural and investment policy that is focused on ensuring sustainable economic growth. At the same time, the budget regulation mechanism remains the most effective tool. Increase in investment activity and reduction in regional asymmetry is objectively impossible for some municipalities without government support due to an

*Corresponding author: rnataliau@mail.ru 
acute shortage of financial resources [1].

However, as practice shows, even an actively pursued policy of budgetary regulation does not always bring positive results, which lead to an imbalance contraction and an increase in the level of development of certain subjects of the Russian Federation or municipalities. And this is one of the reasons why the development and implementation of regional policy measures to eliminate imbalances and reduce asymmetry in the economic growth of territories is designated as a priority at the state level. This situation indicates the need and relevance to study this field and to search for new approaches to solving the problem of the balanced development of territorial entities [2].

\section{Materials and Methods}

The essence, causes and consequences of the uneven development of territories in the traditional regional economy have always been the subject under serious research and allowed not only in theoretical but also in practical aspect to recommend specific development models and regulatory mechanisms. In a planned economy, this task had its own specifics, and, in terms of the market, it requires transformation taking into account modern scientific paradigms and realities in the development of regions. In addition, objectively territorial differentiation with the transition of the economy to a market footing, has changed due to new trends in the economy.

A.G. Granberg, exploring the objective reasons for the economic differences between the regions of Russia in the process of modern market transformation of the Russian economic space, identifies three main points:

- continuation of the socio-economic differentiation of regions;

- interweaving of disintegration and integration processes;

- a sharp transition from economic recession to economic growth with significant regional features [3].

Along with objective reasons, one should take into account subjective and, above all, the influence of administrative regulation on the development of socio-economic processes in the regions. The paradox is that the adoption of administrative decisions is generally intended to eliminate imbalance, but in some cases can lead to increased differentiation. In addition, it should be borne in mind that it is impossible to determine the optimal boundaries of differentiation, neither by modeling the process of development, nor from the position of practical implications.

Moreover, there is no clear distinction between concepts characterizing unevenness, differentiation, economic features, disproportions, asymmetry, etc. Considering the uneven regional development, a number of scholars rely on the concept of territorial differentiation. But at the same time, the key aspect in understanding the essence of territorial differences is the concept of the integrity of the regional system [4].

Without examining in detail in this work the categories related to the uneven development of territories, they should be taken into accout due to the fact that it is necessary to understand that the differences remain in any economic system when specific approaches and mechanisms are developed. The fact that the task of bringing all regions to one level is unrealistic does not require proof. However, a significant imbalance in regional economies can lead to undesirable consequences, which demands to carry out a wellthought-out structural and investment policy for specific territories.

In order to define a significant unevenness or imbalance in economic systems in the Russian theory and practice, the concept of "asymmetry" is used, which is interpreted as a violation of proportionality or "simmetria" (Greek). B.L. Lavrovsky distinguishes three types of economic state, regarding territorial entities: asymmetrical, (imbalanced), symmetrical (balanced) and neutral [5]. The first type is characterized by an increase in the 
gap between the economic indicators by regions, primarily due to the performance deterioration of depressed economies. With a neutral type of development, the ratio in the level of regional indicators during the period remains unchanged, which indicates a low activity of business administrative structures or an inefficient system of budget regulation. A type of regional development is called balanced or symmetrical, if the imbalances are leveled and the applied mechanisms work a positive result.

Smoothing the economic asymmetry is one of the most important objectives of the state. But trying to eliminate an imbalance in regional development, the system must be kept integral; it can lose the balance and the situation can change not for the better, including from a socio-ethical point of view.

The mechanism of budgetary regulation, as the most efficient in reducing economic differences, mainly is the only tool used in the field. Real and effective assistance to municipalities is provided, but the reasons behind the existing asymmetry and its consequences are not identified. Moreover, depressed areas develop a welfare mentality and unwillingness to independently search for ways out of the crisis or opportunities for growth.

Analysis of the development level of the regions in Russia indicates that the phenomenon of asymmetry is typical for almost all Federation Subjects. Table 1 presents information that displays the differences in the main socio-economic indicators and consistent differentiation in the districts of the Voronezh region. Even on the basis of the analysis of several districts, it can be concluded that there is asymmetry in the development of regions. A complete analysis of all areas, that has been carried out over several years in preparation of this work, proves this.

Table 1. Integral assessment of the level of socio-economic development of municipalities in the Voronezh region for 2016-2017.

\begin{tabular}{|l|c|c|c|c|c|c|}
\hline \multirow{2}{*}{ Indicator name } & \multicolumn{3}{|c|}{ Value of estimate indicators for the districts of the region } \\
\cline { 2 - 7 } & $\begin{array}{l}\text { Petropavlovsky } \\
\text { municipal district }\end{array}$ & \multicolumn{2}{c|}{$\begin{array}{c}\text { Podgorensky } \\
\text { municipal district }\end{array}$} & $\begin{array}{c}\text { Bogucharsky } \\
\text { municipal } \\
\text { district }\end{array}$ \\
\cline { 2 - 7 } & 2016 & 2017 & 2016 & 2017 & 2016 & 2017 \\
\hline $\begin{array}{l}\text { 1. The consolidated indicator of } \\
\text { the level of development of } \\
\text { activities industry and } \\
\text { agriculture per capita }\end{array}$ & -21 & -21 & 2 & 2 & -18 & -18 \\
\hline $\begin{array}{l}\text { 2. The volume of investment in } \\
\text { fixed capital per capita }\end{array}$ & -27 & -25 & -12 & -12 & 3 & 2 \\
\hline 3. Financial security per capita & -26 & -27 & -3 & 2 & -19 & -5 \\
\hline $\begin{array}{l}\text { 4. The proportion of the number } \\
\text { of workers employed in small } \\
\text { enterprises to the number of } \\
\text { employed population }\end{array}$ & -19 & -14 & -25 & -24 & -2 & -7 \\
\hline $\begin{array}{l}\text { 5. The total turnover of retail } \\
\text { trade and paid services per capita }\end{array}$ & -21 & -31 & -24 & -23 & -2 & -3 \\
\hline $\begin{array}{l}\text { 6. The cost of fixed assets per } \\
\text { capita }\end{array}$ & -28 & -28 & 4 & 3 & -26 & -13 \\
\hline 7. Registered unemployment rate & -19 & -23 & 0 & -6 & -12 & -15 \\
\hline $\begin{array}{l}\text { 8. The ratio of the average per } \\
\text { capita financial income of the } \\
\text { population and the average } \\
\text { annual subsistence minimum }\end{array}$ & -28 & -29 & -27 & -22 & -16 & -16 \\
\hline $\begin{array}{l}\text { 9. Provision of pre-school } \\
\text { institutions }\end{array}$ & -18 & -19 & -5 & -10 & -6 & -13 \\
\hline $\begin{array}{l}\text { 10. Consolidated indicator of the } \\
\text { level of health service }\end{array}$ & -6.7 & -6 & -12.7 & -11.3 & -11.4 & -12 \\
\hline
\end{tabular}




\begin{tabular}{|l|c|c|c|c|c|c|}
\hline $\begin{array}{l}\text { 11. The indicator of natural } \\
\text { growth (loss) of the population }\end{array}$ & -25 & -27 & -18 & -22 & 2 & 2 \\
\hline 12.Crime rate & 27 & 27 & 13 & 11 & 2 & 0 \\
\hline 13. Highway density ratio & 8 & 16 & 15 & 13 & 3 & -2 \\
\hline $\begin{array}{l}\text { 14.Rate of gas infrastructure } \\
\text { development }\end{array}$ & -15 & -6 & -23 & -4 & 6 & 6 \\
\hline $\begin{array}{l}\text { 15. Indicator of improvement of } \\
\text { the housing stock }\end{array}$ & -9.6 & -11 & -11 & -12.6 & -6.7 & -8.5 \\
\hline $\begin{array}{l}\text { Total of the integral estemates of } \\
\text { basic indicators }\end{array}$ & -226.3 & -224.1 & -124.7 & -115.9 & -101.1 & -102.5 \\
\hline $\begin{array}{l}\text { Integral estimate of the level of } \\
\text { economic development }\end{array}$ & -15 & -14.9 & -8.3 & -7.7 & -6.7 & -6.8 \\
\hline Rank of Municipality & 34 & 34 & 25 & 23 & 18 & 14 \\
\hline
\end{tabular}

Analyzing the economy indicators of all territorial entities on the example of the Voronezh region, it can be stated that there are disproportions in the socio-economic development of the regions and the asymmetry does not scale down.

Steadily leading positions are occupied by the city of power industry - Novovoronezh, and the capital of the Black Soil Region - Voronezh. Most of the indicators have display positive dynamics. A positive trend is also observed in Bogucharsky district: occupying the 18 th position in 2016 , it climbed to the 14 th in 2017 . The crime rate decreased in the region, whereas the income of the population became higher. The level of socio-economic development of Podgorensky district also changed slightly: financial security per capita increased.

The lowest position in the rank of municipal districts of Voronezh region is occupied by Petropavlovsky district. Unemployment rate is growing. The share of the average number of workers of small enterprises significantly decreased comparing to the total number of employed population.

The illustration of the existing differences based on the analysis of key economic indicators and indicators of the quality of life of the population in the remaining municipalities of Voronezh region displays a significant asymmetry of economic development.

Budgeting tools of investment activities are actively used in order to reduce the asymmetry in the region, contributing to the reduction of differences between regions and the development of the economies of depressed municipalities.

Thus, the Government of Voronezh region on February 8, 2012, approved the Order No. 47-r "On the approval of the composition of municipal districts with a special system of state support" with the aim of smoothing territorial disproportions, as well as improving the socio-economic situation of the population [6]. Seven districts of the region are classified as depressed: Bogucharsky, Verkhnemamonsky, Kantemirovsky, Petropavlovsky, Repjevsky, Ternovsky and Povorinsky. These areas may apply for additional preferences, such as reducing the burden on the local budget when co-financing capital construction projects, etc.

A positive fact is that the budget support not only stimulated half of the districts to increase investment activity, but also led to a growth in the share of equity financing of capital construction projects. At the same time, entrepreneurial activity in the abovementioned areas grows insignificantly.

Priority in tackling the problem asymmetry in the development of municipalities is given to "formalized" mechanisms of allocating budget funds for the implementation of specific projects. So, for instance, in Voronezh region, this kind of support is provided from the regional budget to projects, that are carried out within the targeted investment program for the development of regions. 
Table 2. Data on the financing of capital construction facilities in depressed areas of Voronezh region in 2016-2017.

\begin{tabular}{|c|c|c|c|c|c|c|}
\hline \multirow[b]{3}{*}{$\begin{array}{c}\text { Name of } \\
\text { municipal } \\
\text { district }\end{array}$} & \multicolumn{3}{|c|}{ Financed in 2016} & \multicolumn{3}{|c|}{ Financed in 2017} \\
\hline & \multirow{2}{*}{$\begin{array}{l}\text { total, } \\
\text { thousand } \\
\text { s of } \\
\text { rubles }\end{array}$} & \multicolumn{2}{|c|}{ including: } & \multirow{2}{*}{$\begin{array}{l}\text { total, } \\
\text { thousands } \\
\text { of rubles }\end{array}$} & \multicolumn{2}{|c|}{ including: } \\
\hline & & $\begin{array}{l}\text { by regional } \\
\text { budget }\end{array}$ & $\begin{array}{c}\text { by } \\
\text { municipal } \\
\text { budget }\end{array}$ & & $\begin{array}{c}\text { by } \\
\text { regional } \\
\text { budget }\end{array}$ & $\begin{array}{c}\text { by } \\
\text { municipal } \\
\text { budget }\end{array}$ \\
\hline Bogucharsky & 56097.9 & 55255.3 & 128.6 & 221048.1 & $\begin{array}{c}216874 . \\
0\end{array}$ & 205.1 \\
\hline $\begin{array}{l}\text { Verkhnemamo } \\
\text { nsky }\end{array}$ & 20629.1 & 20613.4 & 15.8 & 19762.9 & 19750.4 & 12.6 \\
\hline Kantemirovsky & 26144.7 & 26129.8 & 14.9 & 2530.4 & 2529.1 & 1.3 \\
\hline Petropavlovsky & 17331.4 & 17325.8 & 5.6 & 54378.1 & 54323.7 & 54.4 \\
\hline Povorinsky & 45199.8 & 45038.4 & 161.4 & 241621.0 & $\begin{array}{c}241389 . \\
5\end{array}$ & 231.4 \\
\hline Repievsky & 184630.7 & 184450.9 & 179.8 & 85638.0 & 85552.3 & 85.6 \\
\hline Ternovsky & 16900.0 & 16887.8 & 12.3 & 3585.9 & 3585.9 & 0.0 \\
\hline
\end{tabular}

Let us break down the options for co-financing investment development programs on the example of Voronezh region.

Nowadays, municipalities are subsidized to finance investments in capital construction projects and to purchase real estate in municipal ownership as well as to support social and utility infrastructure and to improve living standards of the population in accordance with the procedure for granting, spending and distributing subsidies from the regional budget to the municipal ones in order to co-finance capital investments in municipal property which are carried out from the local budgets, as approved by Decree of Voronezh Region Administration №25 on January 18, 2008 [7, 8].

The share of co-financing is estimated on the basis of the share of funds, that are planned in the local budget and the level of fiscal capacity of the municipality.

The share of the expenditure commitments of the municipality must be sufficient or reasonable, but at the same time it must meet the local budget capacity.

In order to calculate the volume of co-financing of the expenditure commitments of the i-th municipal district (city district) from the regional budget for the next fiscal year, the following formula (1) is used:

$$
\mathrm{SRBi}=100-\mathrm{Li},
$$

where: $\mathrm{SRBi}$ - the share of the regional budget in the financing of capital construction and real estate, \%;

$\mathrm{Li}$ - the level of funding the expenditure commitments of the i-th municipal district (city district) from the local budget for the next fiscal year, $\%$.

Thus, the calculation of the level of co-financing the construction of municipal property from the regional budget (on the example of Voronezh region in 2017) is presented in table 1. 
Table 1. Analysis of the level of co-financing the construction of municipal property from the regional budget (on the example of Voronezh region in 2017).

\begin{tabular}{|c|c|c|c|c|}
\hline $\begin{array}{c}\text { Name of } \\
\text { municipal district }\end{array}$ & $\begin{array}{l}\text { Population, } \\
\text { in thousands }\end{array}$ & $\begin{array}{l}\text { Level of } \\
\text { budget } \\
\text { capacity of the } \\
\text { municipality }\end{array}$ & $\begin{array}{l}\text { Tax revenues of } \\
\text { the } \\
\text { municipality, } \\
\text { thousands of } \\
\text { rubles }\end{array}$ & $\begin{array}{c}\text { Level of } \\
\text { financing of the } \\
\text { expenditure } \\
\text { commitments of the } \\
\text { municipality from } \\
\text { the local budget, \% }\end{array}$ \\
\hline Anninsky & 40.4 & 0.930 & 186227.0 & 1.5 \\
\hline Bobrovsky & 50.4 & 0.875 & 199823.0 & 0.6 \\
\hline Bogucharsky & 35.6 & 0.858 & 138550.0 & 0.3 \\
\hline Buturlinovsky & 47.2 & 0.868 & 173078.0 & 0.4 \\
\hline $\begin{array}{l}\text { Verkhnemamonsk } \\
\text { y }\end{array}$ & 19.4 & 0.908 & 79894.0 & 1.0 \\
\hline Verkhnekhavsky & 24.4 & 0.875 & 104947.0 & 0.5 \\
\hline Vorobievsky & 16.6 & 0.848 & 62086.0 & 0.2 \\
\hline Gribanovsky & 30.8 & 0.939 & 145729.0 & 1.8 \\
\hline Kalacheevsky & 53.2 & 0.864 & 187784.0 & 0.4 \\
\hline Kamensky & 18.7 & 0.853 & 69257.0 & 0.2 \\
\hline Kantemirovsky & 34.7 & 0.894 & 145573.0 & 0.9 \\
\hline Kashirsky & 24.2 & 0.869 & 79972.0 & 0.4 \\
\hline Liskinsky & 101.0 & 1.192 & 602037.0 & 28.0 \\
\hline Nizhnedevitsky & 18.7 & 0.879 & 82967.0 & 0.7 \\
\hline Novousmansky & 80.7 & 0.880 & 298138.0 & 0.7 \\
\hline Novokhopersky & 38.3 & 0.841 & 114676.0 & 0.2 \\
\hline Olkhovatsky & 23.1 & 0.840 & 74089.0 & 0.2 \\
\hline Ostrogozhsky & 59.5 & 1.003 & 191900.0 & 10.1 \\
\hline Pavlovsky & 56.0 & 0.948 & 246144.0 & 2.0 \\
\hline Paninsky & 26.2 & 0.844 & 79299.0 & 0.2 \\
\hline Petropavlovsky & 17.8 & 0.861 & 59965.0 & 0.3 \\
\hline Povorinsky & 32.5 & 0.858 & 105422.0 & 0.3 \\
\hline Podgorensky & 25.0 & 0.854 & 85318.0 & 0.2 \\
\hline Ramonsky & 32.8 & 2.055 & 344797.0 & 30.5 \\
\hline Repievsky & 15.7 & 0.830 & 41144.0 & 0.1 \\
\hline Rossoshansky & 93.2 & 1.088 & 526381.0 & 22.5 \\
\hline Semiluksky & 67.8 & 0.853 & 203053.0 & 0.2 \\
\hline Talovsky & 39.2 & 0.854 & 154630.0 & 0.3 \\
\hline Ternovsky & 19.5 & 0.858 & 67496.0 & 0.3 \\
\hline Khokholsky & 29.7 & 0.872 & 127746.0 & 0.6 \\
\hline Ertilsky & 23.4 & 0.858 & 92918.0 & 0.3 \\
\hline $\begin{array}{l}\text { Borisoglebsky } \\
\text { municipal district }\end{array}$ & 74.8 & 0.847 & 310902.0 & 0.3 \\
\hline $\begin{array}{l}\text { Municipal district } \\
\text { - Voronezh }\end{array}$ & 1032.4 & 1.263 & 7018306.0 & 31.2 \\
\hline $\begin{array}{l}\text { Municipal district } \\
\text { - Novovoronezh } \\
\end{array}$ & 31.5 & 2.158 & 347983.0 & 31.5 \\
\hline
\end{tabular}


The existing procedure allows to determine the share of participation of the regional budget in the co-financing of capital investments, but does not contribute to the increase in investment activity of the regions, as well as the elimination of asymmetry in the level of socio-economic development of the territories. The increase in asymmetry objectively enhances unevenness between municipalities in the possibilities of independent solution of issues related to the provision of current activities and future development. In turn, the unevenness requires the regional center to pay extra attention to the issue of redistributing of financial resources in order to ensure minimum guaranteed state standards $[9,10]$.

Monitoring the level of social and economic development of municipalities allows to evaluate the efficiency of local socio-economic processes management, as well as determine where and what measures of state support are needed first.

\section{Results}

It is advisable to adjust the estimated amount of financing the expenditure commitments of the i-th municipal district (city district) from the local budget for the next fiscal year depending on the level of subsidies to the district in order to balance the level of development of districts and respect the interests of municipalities, budgets of which carry high load. In previously published works, the authors suggested introducing a corrective criterion for the subsidy of a municipality with an account of which the level of financing of the expenditure commitments of a municipality from the local budget will decrease. Thus, it will reduce the burden on local budgets, shorten asymmetry, involve municipalities in more active participation in the bid campaign and improve investing efficiency.

As a result of the introduction of the donation criterion, the level of co-financing changes and most adequately reflects the needs of districts to subsidize the investment programs from the regional budget. The verification of the proposed methodology is given on the example of the Ostrogozhsky municipal district of Voronezh region, which had a budget capacity of 1.003 in 2017 , i.e. greater than 1 .

The level of financing of the expenditure commitments of the municipal district (city district) from the local budget when calculated according to the traditional scheme is $10.1 \%$, and it will decrease to $6.8 \%$ when recalculated according to the suggested methodology.

\section{Discussions}

The active use of the budget mechanism, as one of the efficient tools to reduce imbalance in the economic growth of regions, is important, but not developed enough from the methodological and practical points of view.

The provision, expenditure and distribution of subsidies from the regional budget to local budgets for the co-financing of capital investments in objects of municipal property that are carried out from local budgets are currently pulled off in accordance with the methods approved at the regional level. Such techniques are not perfect and can not take into account the specifics of the municipality. The procedure for calculating the level of cofinancing from the regional budget, presented in this paper, also does not allow to take into account the investment potential of the district, its production and social structure.

Issues related to the financial support of depressed areas, as well as areas that effectively use budget funds and are economically active, remain debatable.

In particular, it is necessary to introduce a system of incentives for areas where, with an increase in subsidies from the regional budget, the number of initiative investment projects is growing and interregional ties are being strengthened, allowing to implement cluster or 
other projects that boost economy in the region as a whole and simultaneously cut the asymmetry.

\section{Conclusion}

The suggested recommendations were tested on the example of a real project implemented in one of the districts of Voronezh region. Investment project - Construction of a dairy complex for 5,000 heads of dairy herds close to Arkhangelskoe in Anninsky district of Voronezh region, OOO "Selskohozyaistvennoe predpriyatie "Moloko Chernozemiya" (Agricultural enterprise Milk Chernozemye LLC), Anninsky municipal district.

The task was to design a complex of 28 buildings and structures with the necessary infrastructure, including: a special-purpose building for 792 cattle heads, 6 barns for 840 heads of dairy herds, a housing for keeping dry cows and heifers, a milking parlor and a number of other facilities. The volume of investments is 3512.00 million rubles (1241 million rubles - municipal funds, 2271 million rubles - borrowed funds).

A dairy complex for 5,000 head of dairy herds was put into operation on the territory of Anninsky district, which is the largest dairy complex in Europe. Therefore, the production of raw milk in the region has been increased, that will contribute to improving the food security in Voronezh region and Russia as a whole. Since 2018, the production capacity is 38.90 thousand tons of raw milk per year and 1,426 tons of cattle in live weight.

The project created 221 new jobs with a salary level above the industry average. The results of the calculation show that the main goal is being achieved - reducing the burden on the local budget, which is done by taking a more correct account of the level of the district subsidies. Thus, an increase in the investment activity of a municipality can be conducted by a broad system of budget support measures, and also by improving the procedure of estimating the level of co-financing from the municipal budgets.

The results of theoretical studies and analysis of the level of development of the districts of Voronezh region confirm the importance of using budgeting tools to reduce imbalance in the development of territories, including municipalities within each region of the Russian Federation.

\section{References}

1. I.A. Provotorov, M.A. Shibaeva, Improving the efficiency of concession projects (on an example of the Voronezh area the road sector)(VGASU, Voronezh, 2014)

2. J. Monios, R. Bergqvist, Research in Transportation Business \& Management 14, 9096 (2015)

3. M. Arata, M. Petrangeli, et.al., Transportation Research Procedia 14, 343-352 (2016)

4. E.N. Yevstafyev, N.V. Yevstafyev, 21st International Economic Conference IECS, 73$76(2014)$

5. N.V. Evstafyev, E.N. Evstafye, 2nd Global Conference On Business, Economics, Management and Tourism 23, 1060 - 1063 (2015)

6. R.F. Rolima, E. Santos, L. Meirac, Region. XI Congreso de Ingenieria del Transporte, 160-169 (2014)

7. S. Naresh, K. Malhotra, Journal of Business Research 69, 5671-5681 (2016)

8. I.M. Horta, A.S. Camanho, Expert Systems with Applications 41, 974-983 (2014)

9. J. Deng, L. Wang, Swarm and Evolutionary Computation 32, 121 -131 (2017)

10. P. Neirotti, E. Raguseo, Information \& Management 54, 139-153 (2017) 